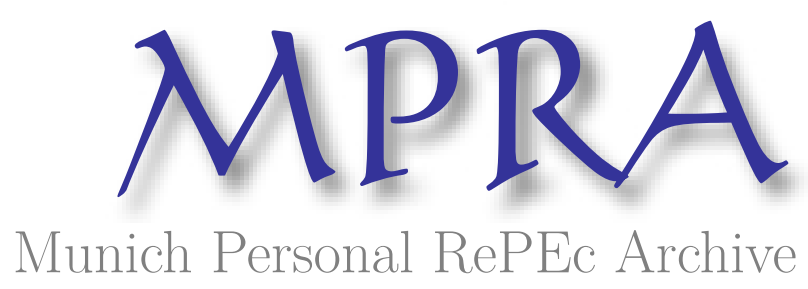

\title{
Emerging markets, industrialisation and economic development
}

Singh, Ajit

University of Cambridge

1 January 1995

Online at https://mpra.ub.uni-muenchen.de/54985/

MPRA Paper No. 54985, posted 02 Apr 2014 19:16 UTC 


\section{Emerging Markets, Industrialisation and Economic Development ${ }^{1}$}

\section{Introduction}

An outstanding feature of the world financial economy during the last decade or so has been the establishment and the very fast expansion of stock markets in developing countries. Between 1982 and 1992 the total combined capitalisation of companies quoted on the emerging markets included in the IFC list rose from less than hundred billion dollars to nearly a trillion U.S. dollars. The corresponding growth in the combined capitalisation of industrial countries market was a little more than three fold - from three trillion to ten trillon U.S. dollars. A number of leading individual emerging markets (e.g. Mexico, Korea, Thailand) recorded more than twenty fold increase in total market capitalisation of companines quoted on the stock exchanges. By the early 1990's capitalisation of many emerging markets, whether considered in absolute terms or as a proportion of GDP, was greater than that of medium sized advanced countries markets in Europe (e.g. Sweden, Denmark and Finland) .

It will be recalled that in the General Theory, Keynes was stringent in his criticism of the role of the stockmarket in relation to industrial investment and the real economy. In a famous passage, in chapter 12 he wrote:"As the organisation of investment markets

1 This is a revised version of the paper presented at the Paris conference in 1992. It draws heavily on, and extends the analysis of, Singh [1993]. 
improves, the risk of the predominance of speculation does, however, increase. In one of the greatest investment markets in the world, namely, New York, the influence of speculation (in the above sense, ie. 'the activity of forecasting the psychology of the market') is enormous. ... Speculators may do no harm as bubbles on a steady stream of enterprise. But the position is serious when enterprise becomes the bubble on a whirlpool of speculation. When the capital development of a country becomes a by-product of the activities of a casino, the job is likely to be ill-done."

That was of course yesterday. Today the stockmarkets are the 'toast of the town'. New ones are being established and existing ones being expanded by developing countries around the globe - from the least developed countries like Tanzania and Nepal to, as seen above, the most advanced of the industrilizing economies like Korea and Taiwan. Despite the huge stock market scam in India in 1992, almost every important city in the country, either already has or aspires to have a stock exchange. Interestingly, stock markets are being favoured, not just by the Bretton Woods institutions (as one would expect), but also in heterodox circles. For example, a WIDER Study Group in Helsinki in its 1990 report strongly recommended the establishment of such markets in poor countries in order to attract portfolio investment funds from rich countries.

More significantly, the communist government in China is fast expanding stock markets. In his Report to the 13th Congress of the 
Chinese Communist Party in 1988, the then General Secretary of the party Zhao Zhi Yang provided an ideological justification for the use of the stock market by a socialist economy. He suggested that during the 'primary state of socialism', and the 'commodity production' stages of the development of a socialist economy, it is necessary to use various market forms including the stock market. Zhao argued that such institutions should not simply be regarded as a preserve of capitalism: socialism should also take advantage of them whilst minimising their harmful effects ${ }^{2}$.

Notwithstanding this almost universal enthusiasm in third world countries for stock markets, it is important to be cautious about the role of these markets in economic development. This is not just because of Keynes' strictures above. More importantly there is very considerable concern today in the US and the UK themselves countries where stock markets are more advanced and reign supreme - about the negative effects of these markets on these nations' competitiveness vis-a-vis countries like Germany and Japan (where equity markets have historically been far less significant in relation to industrial development). A growing number of economists and industrialists in both the US and the UK believe that stock market - based economies are at a competitive disadvantage in relation to Germany and Japan which have bank based financial systems. Stock markets, it is contended, lead inevitably to short-termism. They tend to become vehicles for short-term gains

2 For a full discussion of the role of the stock market in a socialist economy, see Singh [1990]. 
(through, for example, leverage buy-outs and hostile takeovers), rather than promoting long-term investment.

Professor Michael Porter of the Harvard Business School, reporting recently on the results of a large research project on various aspects of the US financial system, voices these concerns as follows: "..the change in nature of competition and the increasing pressure of globalization make investment the most critical determinant of competetive advantage. ... Yet the US system of allocating investment capital both within and across companies is failing. This puts American companies at a serious disadvantage in global competition and ultimately threatens the long term growth of the US economy." ${ }^{3}$

In view of these contradictory assessments of the role of the stock market for competitiveness and long term investment and innovation, it is essential for the developing countries before they go too far in this direction to ask how precisely do the stock markets help in the industrialisation process. Specifically, the following issues need careful investigation.

(a) What are the channels through which the establishment of a stock market fosters economic and industrial development in a country?

3 Porter [1992a, p.65]. This paper reports the findings of a large research project sponsored by the Harvard Business School and the Council on Competitiveness, a project that included 18 research papers by 25 academic experts.) 
(b) How well do such channels operate in practice in countries which have well functioning stock markets?

(c) How are stock markets likely to function in the particular circumstances of developing countries?

(d) If stock market are established, can the developing countries avoid their negative effects as Zhao Zhi Yang was suggesting?

(e) Are there feasible alternatives to stock market-based financial systems? Will the developing countries be better off with such alternatives systems?

Following sections will attempt to shed light on some of these issues.

\section{The Stock Market and Economic and Industrial Development: The Channels of Transmission: Theories and Evidence ${ }^{4}$}

In principle a well functioning stock market may help the development process in an economy through the following means: ${ }^{5}$

1. Growth of savings and investments

2. Efficient allocation of investment resources

3. Better utilisation of the existing resources and an increase in the productivity of investment

4 The discussion in this section draws on my paper Singh, 1990.

5 See for example Baumol [1966], Cho [1986], Stiglitz [1991], Singh [1971, 1992]. 
These three developmental tasks are performed on the stock market by essentially two kinds of market mechanisms: the pricing process and the take-over mechanism. The important question is how well do these mechanisms work in practice and how successfully are the above functions in fact performed in the real world. We shall first consider here analysis and evidence in relation to the fully developed stock markets of advanced economies

There is a voluminous literature on this subject, but our discussion here will inevitably be brief and concentrate only on the essential points. ${ }^{6}$ The stock market may encourage savings in developing countries by providing households with an additional instrument which may better meet their risk preferences and liquidity needs. Moreover, share ownership provides individuals with a relatively liquid means of sharing risk in investment projects. This may help raise the rate of investment in the economy by enabling investment projects to be undertaken collectively which otherwise may not have occured at all. In practice however, evidence from well developed stock markets indicates that the does not market perform this savings function at all satisfactorily. As Mayer's [1990] analysis of flows of funds data for several industrial countries on a comparable basis over the period 1970 to 1985 shows, the equity market's net contribution to investment needs of the non-financial corporate

\footnotetext{
Singh [1990].
} 
sectors both in the US and the UK was negative over this period. What this indicates is that corporate new issues in these two countries were more than matched by a net redemption of corporate shares (mainly because of takeovers). In other industrial countries, although new issues made a net positive contribution to corporate investment over the period considered, it was extremely small and amounted to no more than 2 to 3 per cent of the total.

Mayer's data also indicates that in all countries the main source of corporate finance is 'retain earnings'. To the extent that the companies use external funds to finance their investment needs, in almost all countries, except the UK, bank finance is by far the most important source of outside funds.

It is important to observe that although the above empirical results undermine the savings function of the stock market, from a theoritical stand point, they are not surprising. Thus, whether or not domestic savings will be enhanced by the institution of the stock market depeneds in theory on the utility function of the household (Pagano 1993). Since the stock market transaction cost that otherwise help improve the efficiency of savings instruments, some households may be able reach their savings targets by doing less savings than before. Moreover, the pattern of corporate financing observed by Mayer for the advanced countries - in which the firms seem to prefer retain earnings to 
debt, and both these to new issues ( so called " pecking order" pattern of finance) is compatible with rational profit maximisation by the firm. Current models of corporate finance, based on theories of assysmetric information, agency cos $t$, transaction cost etc. can rationalise the " pecking order" in terms of normal profit maximisation by firms without invoking any managerial theories of firm (Myers 1984).

The pricing of shares is critical to how well can the stock market perform the allocative functions. An efficient pricing process will reward the well managed and profitable firms by valuing their shares more highly than those of unsuccessful and unprofitable firms. This mechanism lowers the cost of capital to the former and hence ensures a greater allocation of new investment resource to such firms at the expense of the latter group of firms who correspondingly face a higher cost of capital. Thus relative share prices of firms in an 'efficient' pricing system should reflect their relative expected profitability.

Tobin [1984] has made a useful distinction between two concepts of efficiency of share prices: the 'fundamental valuation' efficiency and the 'information arbitrage' efficiency. The latter refers to how quickly all available information is disseminated throughout the market and is incorporated in share prices; the former concept refers to the notion of efficiency outlined in the previous paragraph. Although there are well known anamolies there is considerable evidence from advanced country stock markets which 
indicates that share prices on these markets are "weakly" efficient in the 'information arbitrage' sense: all new information is fairly quickly reflected in share prices. ${ }^{7}$ There is however far less evidence which suggests that actual prices which prevail on the London or New York stock exchanges are 'efficient' from a point of view of fundamental valuation, i.e. that relative share prices of corporations always reflect their true long term expected earnings. Many empirical studies have called attention to myopia, fads, and the domination of stock market prices by short term considerations. ${ }^{8}$ It is the influence of short termism and speculators on the stock market that had led Keynes in the General Theory to liken the stock market to a gambling casino.

Although "efficient" prices in the fundamental valuation sense are a necessary condition for the stock market to perform its developmental tasks, they are not sufficient. Sufficiency requires in addition, the existence of an 'efficient' takeover mechanism which can ensure that all those companies whose profitability under their existing managements was lower than what it could be under any other management, were acquired by the latter. For large management controlled oligopolistic corporations in capitalist economies, for which the natural selection process on

7 See the contributions to the "Symposium on Bubbles" in the Journal of Economic Perspectives, vol 4(2), 1990.

8 See for example Shiller [1981]; Modigliani and Cohen [1979]; Poterba and Summers [1988]; Smith, Suchaneck and Arlington [1988]; Nickell and Wadhwani [1987]. For a careful recent review of the burgeoning theoretical and empirical literature in this area see Camerer [1989]. 
the product markets may not work, the takeover mechanism is the only effective marked-based disciplinary device. ${ }^{9}$ However, modern theorists of the firm and industrial organisation have argued in recent contributions that for a number of powerful reasons (e.g. the transactions costs, the 'free rider' problem), even in principle, the takeover device may not work effectively despite the fact that the pricing process of the stock market were "efficient. ${ }^{10}$

More significantly, empirical studies of the actual nature of the take- over selection process on the stock market show that contrary to the folklore of capitalism, in general it is not the case that only the unprofitable companies are taken over, or that greater the profitability (or the stock market valuation) of a company, the correspondingly lower its chances of acquisition. Evidence from a wide range of studies for the UK, the US and other industrial countries indicate that the take-over selection takes place only to a very limited degree on the basis of profitability; it does so much more in terms of the size of the company. A large, relatively unprofitable company has a much greater change of being immune from take over than a much more profitable but a small company. In fact, in the real world stock markets, making an acquisition to increase size might itself become a tactic to avoid take over. (Greer, 1986; Singh, 1971).

9 There is a large literature on the subject. For a recent review article see Singh [1992].

10 See for example Grossman and Hart [1980]; Stiglitz [1985]. 
If we turn from the question of what kinds of companies are taken over on the stock market and by whom to that of what happens to resource use following takeover, the empirical evidence is no more reassuring. In addition to their disciplinary role, takeovers also provide an important mechanism in a capitalist economy for the reorganisation of the capital resources of the society in response to changing technology, tastes, and market conditions. However a wide range of empirical studies comparing pre - and post merger profitability indicate that, on average, the profitability of merging firms does not improve after merger. To the extent that monopoly power of the acquiring company in the product market may increase as a consequence of takeover, this evidence is compatible with reduced efficiency in resource utilisation following mergers. ${ }^{11}$

If the post-merger outcome of the amalgamation process is considered in terms of the effect on share prices (rather than on the accounting rates of return), the results of empirical studies suggest that the shareholders of the victims invariably gain as a consequence of takeover (due to the bid premia) whilst those of the acquirers do not. These bid premia on taken over companies are regarded by economists who believe in the 'efficiency' of the stock market pricing and takeover processes, as indicators of unrealised long-term efficiency gains. It is however, more natural to think of them as arising from the 'dual valuation' situation which exists 11 See Singh [1971, 75, 93]; Meeks [1977]; Mueller [1980]. 
on the stock market in relation to takeovers (Charkham, 1988; Plender, 1990): one is the normal day-to-day valuation of a small number of a company's shares which may be traded and reflects valuation at the margin; the other is the valuation for the control of the company as a whole when intra-marginal holders have to be bought out (Hughes, 1989). The differences between these two valuations provide enormous opportunities for predators, speculators and others who may gain simply putting a 'company into play' regardless of the economic and industrial logic of the acquisition. ${ }^{12}$

To sum up the above analysis suggests that even with well organised and complex stock markets such as those which exist in the US and the UK, the stock market is unable to perform its disciplinary and allocative tasks at all well; nor is it conspicuously successful in promoting savings. However the fact that the stock markets may not confer much benefit on the advanced countries does not mean that their influence is nevertheless generally benign or at least harmless. As noted in Section I, there are good analytical reasons for the view that the active role which the stock markets play in the US and the UK may actually be damaging to these economies. This theme will be explored in the next section by comparing the characteristics and experience of the Anglo-saxon economies with those of Japan and Germany where the stock market for historical

12 For a fuller discussion of the diffrences between the merger studies based on accouting and share price data see Caves (1989), Scherer ( ), Singh (1993). 
reasons has traditionally had very little influence on industrial development.

\section{The Stock Market, Takeovers and International Competitiveness: The Financial Systems in the US and the UK Versus West Germany and Japan}

An active market for corporate control with its corollary of hostile takeovers is today a central feature of the finance-industry relationships in the stock market dominated economies of the US and the UK. However the relationships between finance and industry are rather differently organised in Japan and West Germany. In these countries there is a far greater role for the banks who tend to have a long term relationship with industrial corporations. There is also a rather different status for the shareholders and the stock market in general than in the Anglo-Saxon economies. Both in Japan and West Germany hostile takeovers are virtually absent

As Mr. Kazuo Nukazawa, a managing director of Keidanren (the Japanese employers federation) explains:

'Ours is not the rugged or brutal capitalism of the eighteenth and nineteenth century. When good management today involves not just production and sales but also integration with the corporate and social environment, a takeover objected to by such "stake-holders" is doomed to fail in the long run. ${ }^{13}$

13 Quoted in Cosh, Hughes and Singh [1990]. 
In the Japanese scheme of things, the shareholders are placed a 'distant last', behind almost everyone else who has dealings with the company - the so-called stake-holders. ${ }^{14}$ The latter include managers, employees, creditors, banks, customers and suppliers and, if the company is a part of a large group, the parent company. Takeovers cannot be successfully completed without the consent of the significant stake-holders in each case.

In Germany also the incidence of hostile takeovers is very low. Moreover, the size of the German stock market is relatively small; the ratio of marker capitalisation to GDP is about 25 per cent in Germany as compared to 80 per cent in Japan, 85 per cent in the UK, and 87 per cent in the US. Of around 400 companies quoted on the German stock markets only about 30 have shares which are actively traded (the other companies being closely held and therefore much less subject to a takeover threat).

Some recent academic research on both sides of the Atlantic links the competitive failure of the Anglo-saxon economies (relative to those of Japan and Germany, for example) to the differences in the operation of the market for corporate control and other features of the financial systems of these countries. At the simplest level the argument is that the existence of a highly active market for corporate control, with its hostile take-overs and leveraged buy-outs oblidges the U.S. and the U.K

14 See the Economist, 29 April, 1989. 
managers to pay close attention to their earnings per share performances every quarter or every six months. This forces them to become "short-termist" in their outlook and to sacrifice long term useful investments at the altar of short term earnings. ${ }^{15}$

A related point is made in the recent MIT Commission Report on U.S. industrial productivity (MIT, 1989), which suggests that U.S. industries have lost out to the Japanese not because Japanese wages are relatively low, but because the relative cost of capital and the threshold rate of return in Japan are much lower. The Commission gives examples of a number of American markets where Japanese have come in, accepted a very low rate of return, while the American companies have diversified and left those markets, since they could not accept such low returns. Japanese companies are able to sustain such low rates of return for prolonged periods because they are not subject to the constant take-over threat of the kind which the American

firms have to endure.

The Japanese and also the West German financial systems, which are bank rather than stock-market-dominated, are thus on this analysis regarded as being much more conducive to the development of the real economy and to international competitiveness. This modern thesis connects with an influential earlier analysis by economic historians, such as Gerschenkron [1962], Cameron [1967] and others,

15 See for example Cosh, Hughes and Singh [1990]; Frank and Mayer [1990]; Berger et.al [1989]. For a fuller discussion of the relationship between takeovers and short-termism see Singh [1993a]. 
who called attention to the critical role of the banks in initiating and fostering industrial development during the last century in Germany, France and Japan.

Keynes observed in the General Theory: 'the spectacle of modern investment markets has sometimes moved me towards the conclusion that to make the purchase of an investment permanent and indissoluble, like marriage, except by reason of death or other great cause, might be a useful remedy for our contemporary evils. For this would forced the investor to direct his mind to the long term prospects and to those only' (chapter 12). Characteristically Keynes puts his finger on a central analytical weakness of a stock market system with respect to the finance-industry relationship. An important feature of a stock market is that it provides the individual investor with more or less ready liquidity. This is usually regarded as a virtue by the exponents of the stock market. As Mr John Tagino, a former head of global equity trading at Merrill Lynch put it in relation to the global equities market for leading corporations: '(it) gives the customer the ability to have instant liquidity at any time of the day or night, he or she wants it'. ${ }^{16}$ However this 'liquidity' also means that the investor need have no commitment to the long term future of the firm. The bank-dominated financial systems are by contrast far better able to ensure such long term financial commitment to their client corporations. Moreover, unlike the small individual investor in a stock market system who has no incentive to gather the costly

16 Quoted in Cosh, Hughes and Singh [1989]. 
information to supervise and discipline managers in management controlled large corporations, the banks have both the incentive and capacity to subject corporate managers to much more stringent supervision. The German-Japanese types of banks are thus able to cope far better with the problems of asymmetric information, agency costs, transaction costs than the Anglo-Saxon stock market system.

The above discussion raised the question that if bank-based financial systems have such obvious advantages over the market-based systems, why in the recent period have countries like Japan and Germany been liberalising the financial systems and making them more market - oriented. However, the impetus for such liberalisation in countries like Japan and West Germany comes from the current imbalances in the world economy and from the US political pressure than from the exigencies of economic development. For reasons given above investment and economic growth in the hitherto non-stock market economies are more likely to be harmed rather than helped by the globalisation and liberalisation of financial markets which is presently taking place. 17

\section{Third World Stock Markets, Volatility, New Issues and Foreign Portfolio Investment}

17 See further Cosh, Hughes and Singh [1989; Mayer [1988] and Frank and Mayer [1990]. 
Apart from all the problems associated with the finance - industry relationships which even well organised stock markets have, most third world stock markets are in their infancy. They tend therefore to be shallow; they do not yet have fully developed systems of regulation, accounting standards, etc. Although in all these respects, these markets may be expected to improve over time and behave more like advanced country stock markets, research suggests that they currently display certain special characteristics. These will be briefly taken up in this section.

\section{IV.1 Volatility}

Stock market prices tend to fluctuate more than other economic variables even in fully developed markets. However, the high degree of volatility is a negative future of stock markets in that it can undermine the financial system as a whole; it also makes share prices much less useful as a guide to the allocation of resources. Moreover to the extent that they discourage risk-averse savers and investors, stock market fluctuations may raise the cost of capital to corporations. After the 1987 stock market crash, several enquiries were undertaken in the United States (e.g. the Brady Commission) to see whether as a result of financial liberalisation and global trading, or the introduction of new technology and devices such as programme trading, stock market volatility on the U.S. market has increased, and how in any case it can be reduced. Evidence however indicates that volatility on the US market in the 1980s has been much in line with the long term historical record; it has in fact been less in the last decade than 
in the 1930s. (Schwert, 1989). Nevertheless it remains a cause for concern and several proposals have been put forward to reduce share price fluctuations, e.g. suspension of share trading if the stock market index falls by more than a specific percentage in a trading period.

However the capital markets of developing countries exhibit much greater volatility than those of advanced economies. Singh (1993) provides evidence on this issue for the 1980's. His data show, for example, that between 1984 to 89, the standard deviations of monthly percentage changes in share price on the emerging markets were considerably larger than those on the US, the UK or the Japanese stock markets. Singh also reports that between 1982 and 1985, share prices on the Brazilian stock market rose five fold (in US dollars terms); two year later they dwindled to twenty eight per cent of their 1985 value. In the first nine months of 1987, share price on the Mexican stock market rose six-fold. However, following Black Monday in October 1987 prices fell to a tenth of their pre crash level. In Taiwan, the largest third world stock market, between 1987 and February 1990, the share price index rose by three hundred and thirty per cent to reach a peak of 12,600 ; the index then fell to a quarter of its value (3160) by September 1990. ${ }^{18}$

A priori, the reasons for the greater price fluctuations on the third world stock markets are not be far to seek. First, because these countries do not as yet have the accounting standards, or

18 Financial Times, 20 Sept., 1990 
possess in sufficient numbers information - gathering and disseminating private firms or public organisations of kind found in developed countries, the share prices in these emerging markets are likely to be dominated by 'noise' and speculation. Second, the fact that not many listed companies in these young markets will have a long enough track record, or sufficient time to establish reputations, will tend to produce market volatility and arbitrary prices.

\section{IV.2 New Issues and Equity Financing}

It was seen earlier that equity financing makes a very small contribution to the growth of corporations in the advanced countries - because of takeovers, in the US, and the UK, the equity market's net contribution to financing of corporate growth has in fact been negative in recent years. However up to now very little information has been available on the patterns of corporate finance in developing countries. In the first study of its kind, Singh and Hamid (1992) have analysed corporate financial structures in nine developing countries over the period 1980-1988. The countries studied included: South Korea, Thailand, Malaysia, Pakistan, India, Turkey, Mexico, Jordan and Zimbabwe. Singh and Hamid's sample frame was the 50 largest manufacturing firms quoted on the stock markets in each of these countries.

This research revealed some very important differences in the financing of corporate growth in the developed and the developing 
countries. Unlike the advanced country corporations, firms in developing countries were found to use external finance to a far larger extent. For example, the median Korean corporation among the top 50 financed nearly 90 per cent of its growth from external sources in the 1980s; the corresponding figure for the median Mexican, Thai and Turkish corporations was, in each case, more than 80 per cent. These are extremely high percentages relative to the experience of developed countries. Secondly, and equally significantly, in more than half the countries in the Singh and Hamid sample, the top corporations used much more equity, rather than debt, to finance the growth of their net assets in the last decade. The largest quoted Jordanian firms financed more than 50 percent of their growth from equity issues and the biggest Turkish firms over 60 percent. Although the median South Korean company used relatively more debt than equity, more than 40 percent of its growth was financed by equity. These surprisng results with respect to the pattern of corporate financing in industrialised economies have been confirmed in Singh's [1995] subsequent study which is based on a much larger data set.

Thus in the developing countries today, with many of them enjoying a stock market boom in recent years, new issues seem to be a genuine source of finance for corporate expansion. However, the important question is whether the development or the expansion of the stock markets in these economies has led to an increase in aggregate savings or that it simply represents the substitution of one form of saving (say bank saving or government bonds) for another 
(purchase of corporate shares in the stock market). There is little no evidence of an increase in aggregate savings for most developing countries as a result of greater new issue activity on the stock market. In some of the countries (e.g. Mexico, Turkey, ) the aggregate savings actually fell during the 1980s. Even if aggregate savings do not rise in a country, for reasons outlined in the forgoing sections, it could be argued that the stock market is still useful in so far as it leads to a more efficient allocation of these savings or to better corporate performance as a result of stock market exposure. There is no evidence in the developing countries on the latter issue although as seen earlier the results of the research from advanced countries on the operations of the market for corporate control are far from reassuring. With respect to more efficient allocation of savings, the high volatility of share prices on the developing countries stock markets and the apparent domination of many of these markets by speculators, does not augur well for this hypothesis either.

It has sometime been suggested that since the developing countries have regulated financial systems, speculation in the stock markets act as release valve that in a free system will be expressed elsewhere. However for all its faults, it is better to allow speculation in gold or real estate than in corporate shares which concern an economy's directly productive potential. Moreover to the extent that it is thought necessary for the government to cater to the tastes of speculators, it is better to provide them with 
a lottery than a stock market where the underlying assets are nothing less than the country's industrial present and future.

\section{IV.3 Foreign Portfolio Investment}

As noted in the introduction, the WIDER Study Group has strongly argued the case for the abolition of exchange control in developing countries, for the encouragement of third world stock markets and for their opening up to foreign investors in order to attract portfolio investment. The group assume that because of the debt crisis, further capital flows from banks to developing countries on a voluntary basis are unlikely for many years. They however, foresee a great potential in foreign equity investment. The main reasons for their optimism on this score are the very large and rapidly increasing assets of the pension funds, insurance companies and other institutional investors in the advanced countries and their need for portfolio diversification.

The Study Group are right in their belief of the considerable scope for foreign portfolio investments in developing countries. Until now, there has generally been low correlation between share prices in the third world and advanced country stock markets; for some 
of the emerging markets the correlations have been negative during the period 1984-89. 19 This makes investment in third world markets attractive for pension funds and other institutional investors in advanced economies for portfolio diversification and risk spreading.

Nevertheless, as suggested in the analysis of the earlier sections there is a serious negative side to the Study Group's proposals to which they seem not to have given sufficient attention. To briefly recapture the main points, first the abolition of capital controls will make the national economy much more vulnerable both to international macro-economic fluctuations as well as to capital flight. Further, in view of the destabilising feedbacks between the financial and the currency markets, it will make the task of exchange rate management, and hence of inflation, much more difficult. Secondly, stock market volatility could "ceteris-paribus" also adversly affect aggregate investment in the economy. In addition, for reasons explained earlier stock market development may damage industry - financial relationships and harm investment, competitiveness and the real economy. Thirdly, if the Study Group's proposals are adopted, most of this portfolio investment is likely to go to a small number of the most developed third world economies with large corporations and relatively well organised stock markets rather than to a majority of the poor countries. The study Group argue that fostering stock market development will among other

19 See also Cosh, Hughes and Singh [1989]; IMF[1989]. 
things discourage capital flight and in fact bring flight capital back since the market gives wealth holders an attractive alternative vehicle for domestic investment. This argument is plausible but deceptive. This is because capital flight is essentially a consequence of financial and macroeconomic instability; of course in turn it also exacerbates such instability. The existence of a stock market per se is unlikely to help in this respect. In unstable economic conditions, stock

market volatility on the contrary could enhance financi al instanbility and in fact lead to capital flight not least by foreign portfolio investors.

\section{Conclusion}

Essentially this paper suggests that it is arguable that even in advanced countries with well functioning markets, the stock markets more likely do more harm than good to the real economy. The supposed positive contributions of the stock market s (encouragements of savings, more efficient allocation investment resources, the discipline of corporate managements throu gh competitive selection in the market for corporate control),

for
all the reasons discussed earlier, do not materialise in practice. The market
for 
corporate control encourages large companies to expand through takeovers rather than to seek organic growth which promotes economic development. Moreover, it is not at all clear that the takeover selection process leads to the survival of firms which are efficient at creating real wealth rather than being simply skilled in financial engineering.

These unfavourable aspects of the stock market are likely to be particularly important in third world countries with undeveloped stock markets and high volatility of share prices. Therefore, to the extent that developing countires today have a choice they should atempt to foster bank-based financial systems more along the lines of the 'follower' countries (Japan, Germany, France) rather than to establish and encourage stock markets. Historically, these bank-based systems have a proven record of successfully promoting industrial development in these countries. Moreover, as we have seen earlier, the modern theory of information provides strong theoretical reasons for banks to be on the whole more suitable vehicles for achieving these ends than the stock market. The ordinary shareholder of a large corporation has neither the ability nor the incentive to obtain the necessary information (which is costly) to monitor management activities, thus leading him or her to eschew "commitment" to the organization and to prefer liquidity. The banks, on the other and, have both the means and the incentive to collect such information and to take a long 
term view of firms' prospects - a perspective which is vital for industrialization in developing economies.

Notwithstanding these extremely important advantages of bank-based financial systems, it would be a misake not to learn from the experience of the last two decades when, in many developing countries, such systems have performed far from adequately. In a number of developing countries experiencing a high degree of macro-economic instability, bank-based finance has tended to degenerate into inflationary/ inefficient finance. Experience syggests the following to be the most serious shortcomings of such systems in the developing country context:

(a)

"crony

capitalism",

which

finances schemes of particular individuals and families with political connections, rather than promote long term industrial development;

(b) industry-finance links of the bank-based type can in

principle, and sometimes in practice, lead to monopolist ic positions in product markets and thwart entry by new firms, therby hindering efficient industrial development;

(c) imprudent or inadequate government regulations of the banks has sometimes jeopardized the integrity of the financial system 
as a whole (for example Chile, following financial liberalization in the early 1980's).

Thus although bank-based systems are much to be preferred in principle to the stockmarket-based systems, the developi ng countries should pay particular attention to quesions of proper regulation and to the prevention of monopolistic abuse by the

banks.

However, to be realistic, it must be recognised that the stockmarkets in developing countries are today a part of the new economic landscape and notwithstanding their dubious merits in relation to economic development, they are there to stay. The question, therefore, arises how, if at all, can their negative features be contained ? The analysis of previous sections suggests that from the perspective of economic development, an important general policy principle for the LDCs should be to attempt to insulate as far as possible the real industrial economy from the influence of the stock market. In this context, the following kinds of policy proposals require careful consideration by developing country governments. First, they should examine schemes of taxation to reduce share turnover as was mooted by keynes and has more recently been proposed by Tobin in relation to transactions on the international currency markets. Secondly, the developing countries 
should be seriously concerned about the effects of a prospective market for corporate control. Since stockmarkets in these countries are still in their infancy, most of them do not yet have an active market for corporate control (although some takeover bids on the Indian Stockmarkets have been reported in the most recent period). However, as the stockmarkets become more mature and more firmly established, left to itself, the development of a corporate control. This may involve for example major changes in company law, reducing the role of shareholders and enhancing that of the stake-holders or the government in takeover situations. Some of these proposals in relation to the market for corporate control in the UK and the US are examined in singh (1993).

Thirdly to the extent that institutional investors such as pension funds are public agencies which appears to be the case in many developing countries, the governments could use them to maintain more orderly markets. Fourthly, and importantly, the governments should encourage product market competition to discipline corporations rather than to rely on the stock market for this purpose. If a developing country possesses or is able to establish a German-Japanese type financial system, such discipline would be supplemented by the bank monitoring of corporations. To reduce the negative aspects of the role of the stock market would require a full exploration of the policy areas 
outlined above in relation to the specific circumstances of a particular country. 